\title{
Oral traditions in cryptic song lyrics Continuous cultural revitalization in Batuley
}

\author{
A. ROSS GORDON AND SONNY A. DJONLER
}

\begin{abstract}
Oral knowledge and teachings are referenced but not salient in cryptic song lyrics sung at ritual festivals in Batuley villages of the Aru Islands in Eastern Indonesia. The article examines the relation of the lyrics in songs to associated teachings and how they are vitalized and transmitted over centuries with veracity. Song teachings relate to pearl oyster and sea cucumber harvests, and cosmological beliefs associated with the Maluku Siwa-Lima trade-based moiety system, which took on a unique form in the Aru Islands. Song-related teachings demonstrate cultural adaptations giving meaning to centuries of peripheral engagement in hemispheric trade networks by a geographically isolated community. The article evaluates the role of historical truth in building community and identity within a minority culture and language group.
\end{abstract}

KEYWORDS

Oral history; Siwa-Lima; Batuley; Gwatle; Aru Islands; Tambaroro; cryptic song lyrics.

"All history depends ultimately upon its social purpose"

(Thompson and Bornat 2017: 1)

\section{INTRODUCTION}

In this article we examine several "songs as teachings" used at a ritual festival in Batuley (Gwatle) in the Aru Islands of Eastern Indonesia. ${ }^{1,2}$ Map 1 shows the location of the Aru Islands on the periphery of Maluku.

1 We thank the Batuley community for sharing their hospitality and knowledge to support this research.

2 Batuley is the Dobo Malay term used outside the Batuley community. Gwatle is what the people call themselves in their own Gwatle language known as Gwatle Lir. In this article we use "Batuley". European historic accounts use a variety of spellings such as Watelai and Wateley.

The authors can be reached at: ross.gordon@kpu.ca (A. ROSS GORDON), aduargwari@gmail.com (SONNY A. DJONLER). More information about the authors can be found at the end of the article. 


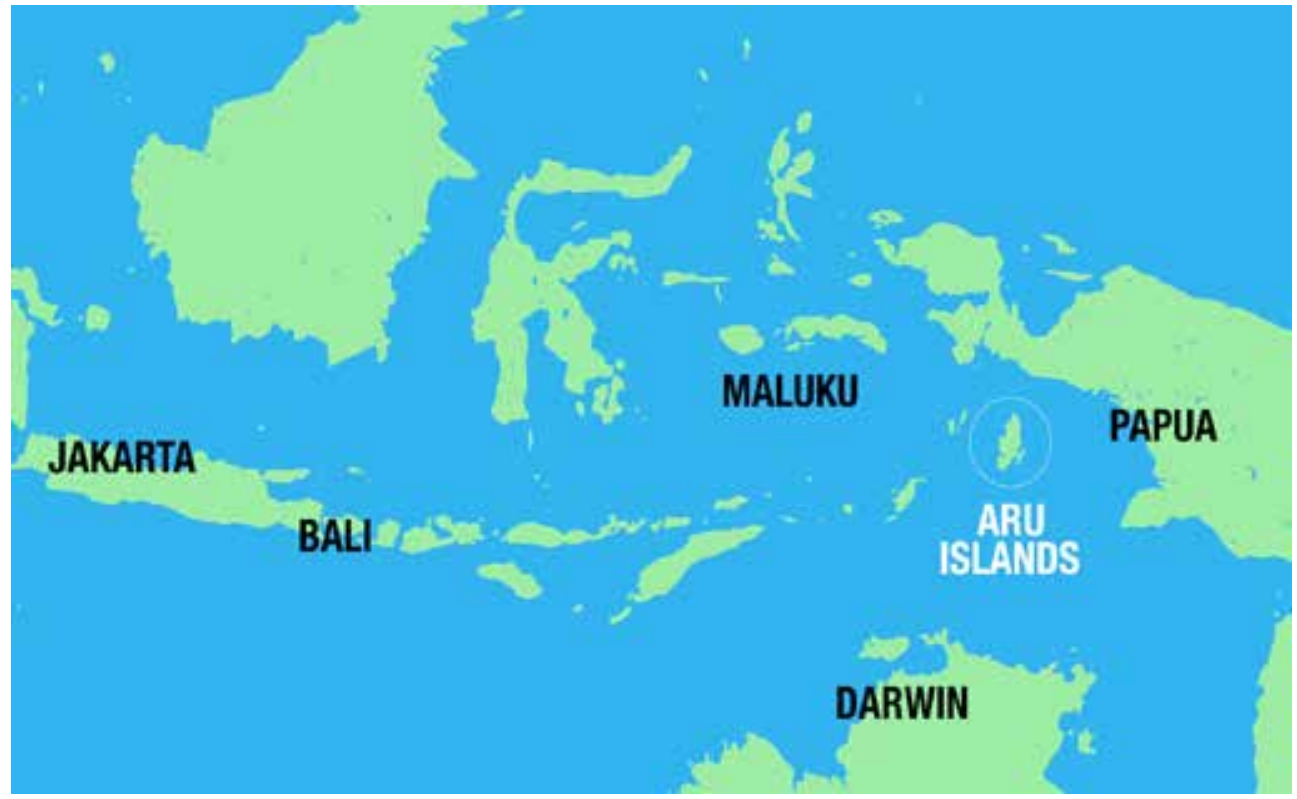

Map 1. The Aru Islands are located on the Sahul shelf joining Papua and Australia under the shallow nutrient rich Arafura Sea.

Ancient events as teachings are remembered in song lyrics that reference, but do not tell the story. The cryptic lyrics limit the knowledge shared with novices or outsiders attending the festival, as was the case when authors Gordon and Djonler were invited to film a Batuley Sea Tambaroro festival in 2014. Over subsequent years we learned stories and meanings referenced in the song lyrics as elders explained knowledge suitable to be shared with the public in film and text. This sharing step is a radical departure in method from the community's established convention of the elders' direct oral transmission of knowledge to select individuals. The complete lyrics of each song we examine are just two or three short phrases repeated many times to form strong mnemonic associations once a lyric is linked with stories of cultural importance.

We argue that the cryptic use of the lyric in public gives value and veracity to the associated historic knowledge. This exclusiveness allows community elders to ensure the content of the knowledge as it is transmitted to select individuals at appropriate times. Batuley people believe that current problems can only be understood and addressed by consideration of relevant historic information. Reliable knowledge of past events is modern wisdom, as events are thought to repeat themselves.

As a source of high value marine resources, Batuley's many centuries of trade-driven interactions with global networks and colonial powers provide rich histories of events to draw upon despite Batuley's geographic isolation. We submit examples to argue that this novel balance of cultural flow buffered by physical barriers is a circumstance supporting the effectiveness of the cryptic song lyric knowledge transmission method. This resilience of this method is an example of what Roy Ellen, in his work on historic Moluccan 
trade, described as "enduring continuities in the local system as it connects with the encompassing changing world" (Ellen 2003: Preface).

\section{MetHODS}

This article follows the path of a Batuley person growing into a responsible role in their community by understanding their history and culture, which includes ancestors and deities described here as meta-persons. We first translate the literal meaning of the song lyric, before expanding its meaning to lead to the stories told by elders in interviews over subsequent years. Sonny Djonler left his natal Batuley village as a youth, so he was learning details of these stories for the first time during the interviews. Although Djonler is taking the initiative in the process, this knowledge transmission pattern resembles the norm of a Batuley man becoming a culture keeper. The interview process does differ from the norm in that the knowledge is being documented in film and text with the involvement of a foreign anthropologist (Gordon).

In the article, we cross-reference the Arunese oral histories with archival references and other research in Maluku to provide context. We assess the veracity of the stories using the concept of historical truth. Culture forms through processes of reifying and transmitting important myths as "historical truths". When people apply "historical truths" as beliefs in everyday life, myths are rendered real as subjective truths (Graeber and Sahlins 2017: 17; Portelli 2017: 13). Our analytical approach does not preclude historical truths being factual truths, which in our Batuley research occurred with impressive accuracy.

Some durable myths are cultural teachings passing wisdom of ongoing relevance through successive generations as social history. Oral historians recognize the importance of holistic analysis of the meaning of the narrative that shapes "emotional communities" through shared experiences that reference important myths (Boschmann 2017; Rosenwein 2006). A shared imaginative experience overlaps a participant's personal truth (Portelli 2017: 11). Congruence of shared experience and personal truth builds emotional communities which in turn belong to a larger emotional community with decreased congruence. Emotional communities exist through sharing affective ways of "valorizing, restraining, and expressing emotions" as norms (Rosenwein 2003: 3). When a community marks important seasonal events through ritual and festival such norms are reified through metaphor, eliciting emotional responses among participants who make the myths memorable.

Our analysis of oral history integrates with the narratives to provide context (Rosaldo 1980: 90). This is necessary to relate the guarded stories with known events and practices. Rules of evidence must be considered for the historic accounts, but we must still value cross-pollinated oral accounts with independent authority, despite some scholarly opinions to the contrary (Vansina 1985: 159). We argue that the stories vitalize emotional communities in a reciprocal cycle that reinforce the teachings. 


\section{Setting: The MaluKu spice trade And the Aru Islands}

A brief historical review provides context for the stories associated with the songs discussed in the article. Ancient Maluku trade networks long incorporated the geographically remote Aru Islands as a peripheral supplier. Centuries before Europeans arrived in Maluku, spice cultivation and long-distance trade flourished through connections within the Indonesian archipelago and further to China, Japan, the Middle East, and onwards to Europe through Arab traders (Brown 1988). For example, greater bird-ofparadise skins and feathers from Aru were exotic trade items with apotropaic powers for Maluku rajahs and Muslim traders in 1523 when Magellan's ships brought the bird skins as a gift for King Charles V of Spain and Holy Roman Emperor (Pires 1944; Swan 2105: 628). The bird-of-paradise export trade has at least a 2000-year history in Aru (Spriggs et al. 2006: 19; see Map 1 for the location of the Aru Islands on the periphery of Maluku).

In the late precolonial and colonial period Aru's outlier role in the Maluku spice trade included supplying slaves and natural resource products to the trade hubs of Ambon and Banda. Islam was well established in the hubs prior to the 1621 Dutch massacre of the bulk of the Bandanese population and the diaspora of the remainder to Ceram, Kei, and Aru that spread knowledge, social networks, and fear of the Dutch (Ellen 2003: 79-85; Hanna 1991: 55; Schapper 2019: 244; Siwa-Lima Museum; VOC 1159). The gradual spread of Islam to Aru demonstrates the reciprocal nature of trade and esoteric knowledge diffusing in erratic stages rather than by large scale conversions. Elements of Islamic practice reached Aru's west coast by the early 1600s but spread slowly in Aru as converts migrated to other Aru communities (Wellfelt and Djonler 2019). In 1872, the European explorer, Luigi D' Albertis visited Batuley, on Aru's east coast, enroute to New Guinea. He described Batuley people as nominal Musselmans, as they did not follow rules of sobriety. D'Albertis marveled at a Chinese storekeeper's "bazaar of European and Chinese articles" and his "two rooms full of mother-of-pearl of first-rate quality" (D'Albertis 1880: 178).

Aru 's role in Maluku trade networks was significant. The export of rich marine resources harvested on Aru's east coast generated reciprocal flows of goods and ideas in Batuley. Small groups of people likely subsisted on local marine resources for millennia on Aru's east coast, but novel economic opportunities arose with Aru's inclusion in the growth of precolonial Maluku trade networks (Spriggs, O'Connor, and Veth 2016: 16). Batuley villages grew in size and importance as exports increased. The effects of trade permeate the stories we recorded. People discussed a concept we translate as their search for livelihood in the sea. It is a way of life, not just a search for material wealth. It was the integration of trade and relationships with meta-persons into Batuley culture that drew our attention. This became apparent as we learned meanings in the cryptic song lyrics that form a mnemonic system for Batuley transmission of culture and self-governance. 


\section{SETTiNG: BAtUley}

The Batuley community of over 3000 people live in seven villages on six small islands on Aru's east coast, known as the backshore. ${ }^{3}$ Batuley Village is considered the ancestral village of the other six villages. ${ }^{4}$ The Batuley people share a distinct language, ${ }^{5}$ but also use an Arunese form of Ambon Malay. The villages sit atop flat limestone cliff edges rising three to nine metres above the high tide level. The houses of the oldest families are at the front or head of the village closest to the sea and surround a sacred space used for ceremonial events such as the Sea Tambaroro festival. The shallow coastal waters of the Arafura Sea limit boat access to the villages to small craft with a local pilot. Electricity is available only from portable generators hampered by the chronic challenge of obtaining fuel. Yet, many homes have amplifiers with large stereo speakers capable of serenading much of the village during generator powered parties. Music is an important social lubricant. There is no cell phone service.

On Aru's west coast, the deep-water port of Dobo is Aru's commercial hub and the modern intersection of Aru's exports, governance, and imports of goods, ideas, and immigrants (See Map 2). Dobo did not exist when Europeans arrived in Aru in the sixteenth century. Batuley people were then trading into Maluku networks through Ujir, an island 20 kilometres north of modern day Dobo, where overseas traders came each year. In the mid-seventeenth century, the Dutch East Indies Company (VOC) established a small fort on Wokam Island, near modern-day Dobo, in order to control the trade. Eventually the Wokam fort was abandoned and by the mid-nineteenth century Dobo was a busy seasonal trade center. "Dobo hub" is the term we use in this article for the Dobo-Ujir-Wokam area. Archival records show Batuley people to be active participants in Aru trade through the trade hub of the time. Geographic isolation is a factor in supporting continuity of Batuley oral tradition, but their culture has a long history of intensive interaction with the overseas world through trade-driven relationships.

Ships arrived in Aru with the west monsoon from Makassar, Seram, Banda, and points west to trade for pearl oyster, trepang (sea cucumber), turtle shell, shark fin, edible bird's nests, bird-of-paradise feathers, and other resources. The ships departed a few months later with the reversal of the winds that closed the main Aru export trade season. Batuley people either travelled to the Dobo hub to trade their harvest or they sold them to resident merchants in Batuley or to independent traders visiting the villages in small boats. This local pattern persists today. The luxury goods trade was reciprocal. Historically,

\footnotetext{
3 The total population of the Aru Islands is 93,780 as of the 2017 census. In 1990 Aru's population was 51,690 (Badan Pusat Statistik 2018) Much of the growth reflects immigration to Dobo from elsewhere in Indonesia.

$4 \quad$ See Wellfelt and Djonler (2019) and Gordon, Djonler, and Hägerdal (2019) for further Batuley historical information.

$5 \quad$ Batuley is a minority language among Aru's 14 languages (Hughes 1987). The Batuley language is classified as a threatened (Lewis, Simons, and Fennig 2015).
} 
imports of gongs and elephant tusks were important bride wealth items. ${ }^{6}$ Chinese porcelain has long served as stored wealth. Considerable amounts of arrack (alcohol) contributed to Aru social life in the past and present (Gordon, Djonler, and Hägerdal 2019; Spyer 2000; Wallace 1869). By the early 1900s, the pearl oyster shell industry was peaking when Dobo was a company town dominated by the Celebes Trading Company (CTC) employing 5000 men in pearling using more than 100 boats in the Aru region (Wollaston 1912: 21). Today, Dobo continues to expand as a bustling entrepreneurial trade port and the bureaucratic center of The Aru Islands Regency.

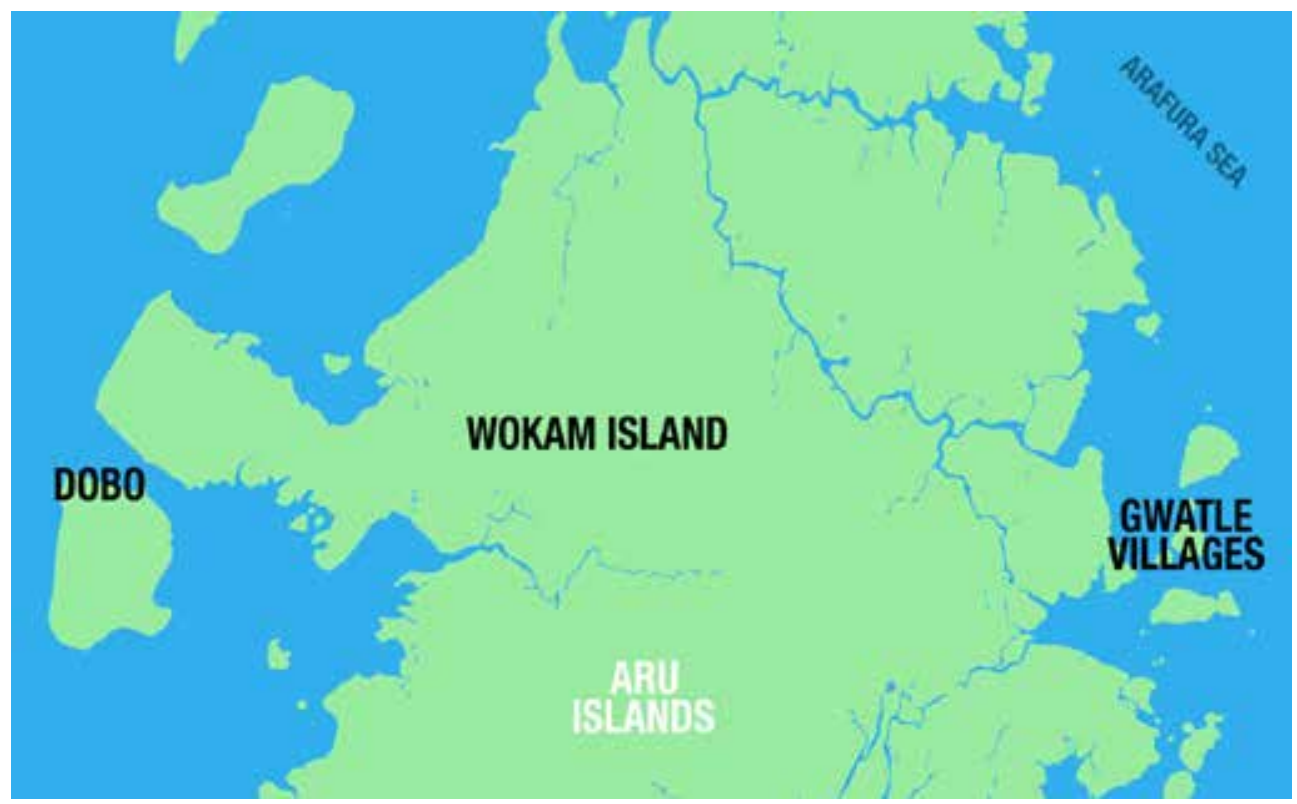

Map 2. This map shows the Batuley (Gwatle) villages on Aru's east coast (backshore) and the deep-water port of Dobo on Aru's west coast. The trip through the shallow tidal channels between Dobo and Batuley usually takes more than 15 hours in a motorized boat and in earlier times was a two to three-day paddle and sail powered trip.

For Batuley people, the settlements in the Dobo hub have long been the primary filter for people, goods, and ideas cycling in and out of Aru. Batuley's physical isolation limits access by outsiders. Batuley village marine tenure systems ensure villagers the option of harvesting high value marine resource trade items. In the past, the geographic isolation offered other advantages. Dominé J. Vertrecht's 1646 account of visiting Wokam frequently mentions concerns about dangerous robbers from Batuley in the Wokam area using five or six boats. This illustrates the active role of Batuley people in the Aru trade hub area (VOC 1159), where piracy was a problem. In 1857, pirates of 
unknown origin were attacking and robbing small trading craft attempting to reach Aru's backshore from Dobo (Wallace 1858: 475). The transportation barriers allowed Batuley people some choice in what goods and ideas they brought home from the Dobo hub. The key point is that Batuley is isolated from the outside world, but also intimately connected. This is pertinent to our discussion of Batuley worldviews and oral knowledge longevity.

Roman Catholic church records of 1954 identify the three Batuley villages of Benjuring, Kabalsien, and Kumul as animist holdouts. Christian churches were established in these villages in the late 1970s (Sol 2009: 58, 90, 159). These conversions to institutional religions in Batuley, and elsewhere on the backshore, were often strategic responses to the Indonesian Government's New Order policy requiring citizens to join one of five world religions (Spyer 1996; Wellfelt and Djonler 2019: 18). Today in Batuley, the three former holdout villages have well-attended Catholic and Protestant churches and Islamic mosques, but the communities also practice ancient adat traditions that bring people of different faiths together, such as the Sea Tambaroro festival in Kumul village where we recorded the songs discussed in this article (Gordon and Djonler 2019a). ${ }^{7}$ The central purpose of this adat festival is to open the harvest season for sea cucumber and pearl oyster.

Of the seven Batuley villages, only the four northern villages hold a Sea Tambaroro festival (see Map 3). Every two or three years, village leaders decide it is time to lift the sasi (prohibition) on sea cucumber collection for three days. Several types of sea cucumbers that flourish in Batuley are in high demand in Asian markets. The sasi ensures stability of the stock in village tenure waters. The three-day harvest period allows village members equal access to the resource. The sea cucumbers mature in 18 months, so the two to three -year gap between harvests allows regeneration of the stock. The Sea Tambaroro festival also launches the annual pearl oyster diving season in the sea cucumber harvest years. Pearl oyster shell is a primary annual income source for many Batuley families. The sea cucumber harvest provides significant extra income every few years to pay off debts, make large purchases, or send children away to school. The three southern Batuley villages no longer hold the festival nor enforce the sasi on their sea cucumber stocks which in 2014 were quite depleted from over-fishing.

\footnotetext{
7 Adat is a generic term invented in 1817 by the Dutch East Indies colonial administration to describe indigenous practices considered as an "undifferentiated whole constituted by morality, customs, and legal institutions" (Franz von Benda-Beckmann and Keebet von Benda-Beckmann 2011: 170). Adat is a set of indigenous customs encompassing spirituality, governance, codes of conduct, access to resources, et cetera, long used in Indonesian communities and best described as "imaginative and adaptive, serving as a living body of agreements, rights, and rules" (Tyson 2011: 655).
} 


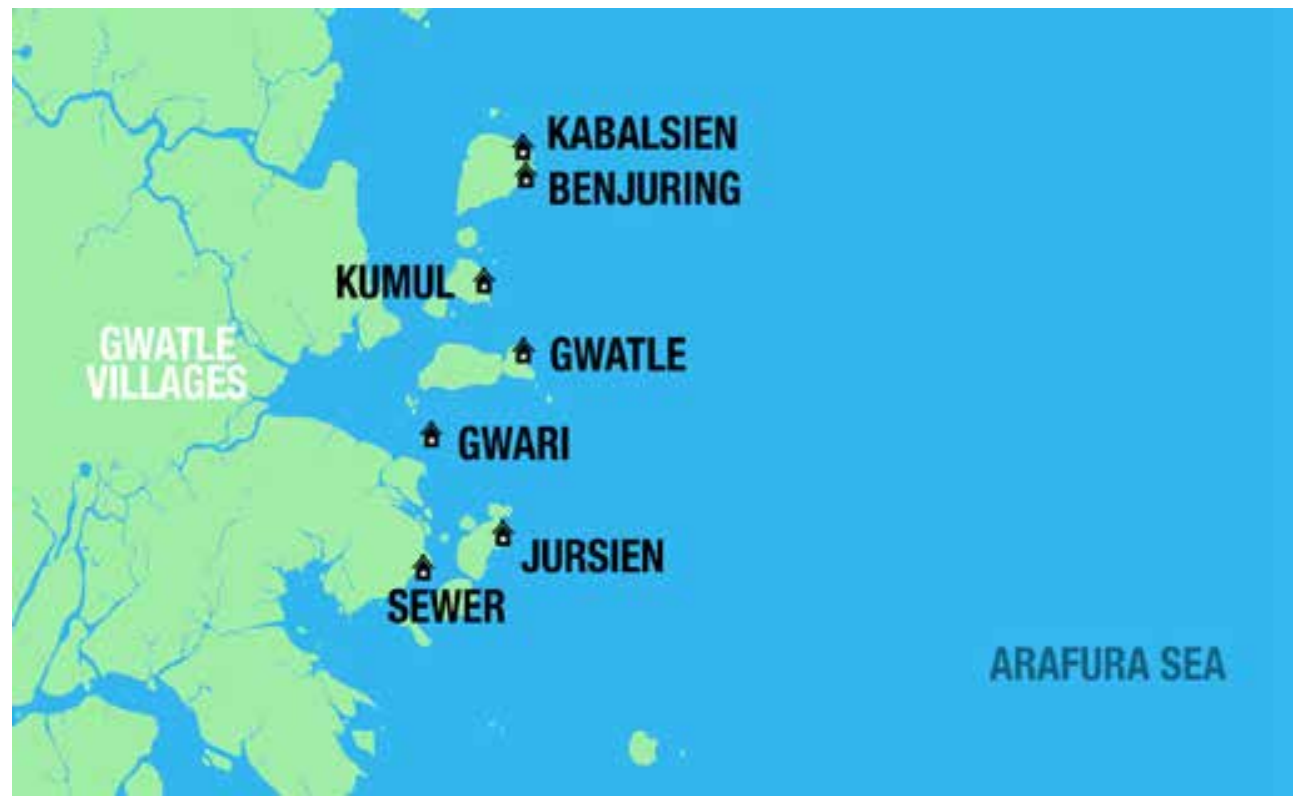

Map 3. The seven Batuley (Gwatle) villages. The Central Gwatle village is considered the ancestral village of the Batuley community.

\section{Sea TAMBARORO FeStival OVERVIEW}

In 2014, the authors filmed the Sea Tambaroro festival held in Kumul village, Batuley. We recorded music, song lyrics and ritual activities and returned to Batuley in both 2015 and 2016 to interview elders and review the rough cut of a film about the event. ${ }^{8}$ The Kumul Sea Tambaroro festival starts after dusk. Men seat themselves inwards on benches along three sides of a rectangle set up near a cliff edge in a sacred space known as the head or front of the village. The men play hand drums and sing in response to the lead singer who stands or sits at a table and chair on the rectangle's fourth end. The expert lead singer knows the words of the songs and determines their order in this part of the ritual lasting from dusk until dawn. The song lyrics recorded during the event often consist of a few phrases repeated many times in a call and response format. Short breaks for smoking and refreshment are taken every hour or two. Nearby the rectangle of benches, a man plays a large gong, and another strikes a smaller gong to create an interlocking rhythm throughout the night as they set the pace for the singers, drummers, and dancers. ${ }^{9}$ Outside

8 Interviews were conducted by Sonny Djonler, a Batuley native who left the village as a youth for education in Dobo and Ambon. Audio-video recordings of songs and festival in 2014 and interviews in 2015 and 2016 were made by Ross Gordon and transcribed and translated by Sonny Djonler primarily using Elan. Some of the audio-video footage is included in the documentary film, Tambaroro (Gordon and Djonler 2019b, 2019c). Raw audio-video files can be accessed in the DoBeS archives (DoBeS).

9 The songs discussed in this article were recorded during this all night 2014 festival. A detailed ethnographic description and analysis of the Sea Tambaroro festival is available (Gordon and Djonler 2019a). 
of the rectangle a rotating cast of other villagers dance. Women ululate (jiljiler in Batuley) at key times to increase the energy of the participants. Another Batuley village, Kabalsien, held a Sea Tambaroro in 2014 with similar logistics for this part of the festival.

The point of the music, dance, and song is to show energetic respect engaging ancestral and sea deities during this important season to sustain Batuley communities. Elders discussed the importance in the event of ngaur, which translates in this case as a combination of liveliness and noisiness achieved in prescribed forms of music and dance. A viable Bahasa Indonesian translation of ngaur is ramai (1 thronged with people. 2 full of action/noise, exciting etcetera) (Stevens and Schmidgall-Tellings 2010). The lyric words sela (cliff) ngaur is the name of an important Sea Tambaroro song. The term sela ngaur also occurs in other song lyrics we recorded at the festival. In some songs the term references times of in-village conflict or preparing for war with others. Elders emphasized the importance of villages generating ngaur to draw the attention of meta-persons to the intent, respect, and energy of the participants. In the words of an elder "we must let the world know" ${ }^{10}$

At daybreak, after the all-night activities finish, about 40 men and boys board a large boat to go out to sea where offerings to sea deities are made in specific places. Their return to the village concludes the festival in Benjuring and Kabalsien, but in Kumul other ritual events proceed through the morning as described in detail elsewhere (Gordon and Djonler 2019a, 2019b). In this article, we focus on two songs sung during the all-night event to demonstrate the complexity, scope, and resiliency of Batuley cultural knowledge referenced in a few short repetitive lyrics. First, we provide the example of another Sea Tambaroro song that first showed us how cryptic song lyrics referenced important knowledge.

\section{AN EXAMPLE OF EMBEDDED CULTURAL WISDOM IN A SONG}

Our inquiries about the song, Kamu buang dia ke tebing-tebing (You cast him away to the cliffs), performed at the Kumul Sea Tambaroro led to several elders telling us similar versions of a story about a violent historic conflict with a Dutch colonial official slain by a Batuley man. The sela ngaur (lively cliffs) lyric occurs in this song too. The story had been transmitted orally through eight named generations. Research in the Dutch East Indies Company (VOC) archives by historian Hans Hägerdal accurately corroborated the Batuley version of the event occurring in 1794. A key difference between the Batuley oral version and the VOC written records was the Batuley emphasis on the personal aspects of human relations among Arunese and Dutch actors, in contrast with the impersonal VOC records relevant to the conflict (Gordon, Djonler, and Hägerdal 2019). Business reports are filed and often forgotten. Songs emphasizing personal experience of significant events give meaning to histories and make them teachings, as will be discussed in relation to other songs below. 
Differences of opinion between Batuley elders from different clans on whether the Batuley protagonist was troublemaker or hero in the 1794 VOC conflict strengthens the resilience of the story. The song lyrics obliquely refer to some unpleasant consequences of the killing for the larger community, but avoid direct reference to the killing, and retaliation carried out by the Dutch in Batuley. The "protagonist as hero community" sing this song together with the "protagonist as troublemaker community" reinforcing the historical truths of the event among the larger emotional community, but with each group keeping their opinions to themselves in the multi-clan setting of the Sea Tambaroro festival. The inherent teachings in the stories associated with the cryptic song lyrics include stories and cultural norms shared in private with select people when appropriate. Examples of teachings from the song, Kamu buang dia ke tebing-tebing (You cast him away to the cliffs) include:

a. Cultural pride in the resilience of Kumul village against violent Dutch governance and attacks;

b. Cultural pride in defending Arunese people against indecent acts by foreign individuals;

c. The risks to the community of members engaging in political intrigues with outside forces. The descendants of the story's Batuley protagonist still carry the mantle of their ancestor's actions. ${ }^{11}$

Historic knowledge and wisdom are held in high esteem in Batuley. When challenges arise, elders start by discussing the history of the event or of similar occurrences. When someone takes on a leadership role, elders spend time teaching them these stories and what was learned from past events. This is a practical method for intergenerational oral history transfer. It is an ingrained central cosmological principle in Batuley that everything repeats itself. Brief cryptic lyrics repeated many times in song are file tabs for complex bodies of knowledge. There is variance in interpretation, but this practice has supported Batuley people's self-governance for centuries balancing the local against significant ongoing interactions with outside forces of resource extraction, governance, institutional religion and more. We use the above story as an clear example of the cryptic lyric and guarded meaning practice because the story focuses on the actions of human beings in recent history verified by oral and written accounts. The two songs presented in this article reference stories of humans and meta-persons in more ancient histories of great importance in Batuley culture, but they lack the archival records of the VOC incident.

\section{THE MUSIC}

Batuley people have at least six broad categories of song types that are demarcated by: when and where the songs are sung; the type of rhythm kept

11 In the Batuley language, the term for politics, katilmeimai, means an entwined version of English language definitions of politics, trickery, and telling lies, which in practice are seldom discrete. 
in the song; and what if any musical instruments are used. The songs we recorded during the all-night portion of the 2014 Sea Tambaroro in Kumul are all classed as mare songs with a similar rhythm kept by hand drums and two gongs of different sizes. There are subcategories of mare amamar (sacred songs) songs, such as the two or three songs prescribed to commence the festival, which are followed by mare fat (regular mare) songs initiated by the song leader or a senior man through the night with some repetition. In Benjuring and Kabalsien villages the festival opens with a song titled Ansob (Our Prayer) followed by Eam Jin (Mother of Pearl Oysters). In Kumul village, Eam Jin is the opening song of the festival, as will be discussed below. These opening songs are sacred components of Batuley spiritual beliefs that blend adat with the influences of meta-persons (local deities, species masters, ${ }^{12}$ and ancestors) as will be shown.

The use of ancient words and language constructions in the cryptic lyrics establishes a linguistic register distinct from everyday speech. Patricia Spyer's analysis of songs of history in another Aru community (Barakai) with ties to Batuley, found that this distinct register made the songs both objective proofs giving authority and sentiment to the history, and embodiments of the historic event referenced in the song (Spyer 2000b: 65-66). Batuley elders stressed the importance of continuity in maintaining the exact lyrics as the ancestors sang them.

\section{Song 1: EAm Jin Ben La Ma (Mother of Pearl Oysters comes from the Sea)}

The core lyric of the song is sung as a "call" by the song leader and repeated many times as a "response" by participants, as follows:

O ben la ma o, e le ben Lour mar o.

Oho eam jin o ben la ma, o le ben Lour mar o a.

'O come from the sea (far away) o, come to Lour channel o'.

'O mother of pearl oyster o come from (far away) the sea, o come to Lour channel o'.

The mother of pearl oyster is a deity or meta-person that we classify as a species master. The Lour channel or Lour mar is believed to be the place in the sea to which Eam Jin comes. Respectful offerings and prayers encourage Eam Jin to bring more pearl oyster clams to the channels in Batuley waters. The shallow coastal seas surrounding Batuley are navigated through networks of channels. The access changes with the tides, waves, and winds. A mar is a small dead-end channel branching from a larger channel known as a jalen or gwalor (Djonler and Gordon 2016: 94). The exact location of Lour channel was not shared with the authors, either because it is sacred knowledge or because it is a metaphorical channel of bounty. One elder told us that Eam Jin

12 A species master is at once: a) an owner, parent, protector of a class of organisms; b) the representative of a class of organisms that also represent the species master; and c) an anthromorphic being (Vivieros de Castro 1992: 345; Sahlins 2017: 42). In Batuley, there are many species masters as defined here. 
originated in the ancient Eno-Karang Island in Southern Aru before moving to Lour Channel, presumably with the exodus of this elder's ancestors from Eno-Karang, a well-known origin story in Aru.

The above lyric about the pearl oyster mother may be repeated for about ten minutes with singers extending the o sound as a variation. The rhythm of the song is typical of the mare songs performed at the Sea Tambaroro. One strike of a large bass gong is followed by two strikes of a smaller higher pitch gong, followed by a rest before the pattern repeats. A dozen or more men playing hand drums keep a steady rhythm following the pattern of the gongs. The term mare applies to a category of songs recognizable by their mare rhythm. The gong players must be consistent in their strokes. One man who took a turn playing a gong was quickly replaced when he faltered on the rhythm. In contrast, youths can take a turn with a hand drum as learners without disrupting the performance. Every so often a lead drummer will play louder to keep everyone on the beat.

The second verse of the Eam Jin song is sung for the species master of sea cucumber and is also repeated many times as follows:

Tangolangola jina ben la ma, ben jau le ma.

'The mother of white-rumped sea cucumbers comes from the sea, comes from far away".

The above song lyrics seem simple at first glance. People want a good harvest season of pearl oyster and sea cucumber, so they sing a request for abundance. However, our interviews on these lyrics yielded consistent deep oral histories. Minor variations were differences in clan histories. We will evaluate these stories to demonstrate how layers of knowledge persist amid cryptic song lyrics. In order to understand these oral histories, we must review Batuley people's cosmological beliefs and kinship systems, knowledge that an apprentice culture keeper needs to understand the meanings in the Eam Jin song. The history is the meaning.

\section{BATULEY SPIRITUAL BELIEFS AND KINSHIP SYSTEMS}

Batuley was considered an animist holdout in Aru before the 1976 Suharto government's requirement for all Indonesian people to join one of five institutional religions (Sol 2009: 58). In Batuley, people officially joined either Protestant, Catholic, or Islamic faiths, of which the latter had been introduced by the mid-nineteenth century in a diluted form (D'Albertis 1880: 178). ${ }^{13}$ In 2014, Batuley churches and mosques were being expanded and renovated. The need for funds to finish the construction of a new Protestant church building was the reason Kumul held an extra sea cucumber harvest in 2014, after a harvest only one year earlier. Kumul villagers all tithed the first share of their 
2014 harvest to the church or mosque of their choice, allowing the Protestants to raise the needed funds from a shared resource equitably. This one-time compromise was brokered through adat practices of community decision making. The Sea Tambaroro festival is an adat ritual. Adat beliefs are strong in Batuley. For example, respect for the sasi (prohibition) on off-season sea cucumber collection is maintained by fear of punishment by spiritual forces. Retribution is delivered through mishap or illness directed by numerous deities, including the sea cucumber species master and the tiger shark who leads justice delivery.

A key societal structure of Batuley, and Aru society in general, are lineagebased clans whose members share expectations of hospitality and cooperation. Clans are subsumed within the Aru moiety system of the opposing "Urlima" and "Ursia" groups, a binary societal division with roots in the pre-colonial Siwa-Lima moiety system in Maluku "that once encompassed all societies from Seram to Aru in the southeast" (Valerio 1989: 117). The origins of the Siwa-Lima system are linked to ancient alliances associated with the spice trade. This is an unusual moiety that lacks intergroup "peaceful exchanges or positive transactions" (Valerio 1989: 122). In Aru the cosmological and political outgrowths of the moiety division outlasted the spice trade foundations. Batuley people belong to the Urlima group, an affiliation often referenced in mare song lyrics.

Origin stories of the different clans in Batuley vary but the stories concur on the point that in ancient times the earliest Batuley ancestors replaced another "primitive" people who lived on the small offshore islands where Batuley villages are today, as shown on Map 3. Djonler, a prominent Aru clan well represented in Batuley, claims an ancient middle eastern heritage. ${ }^{14}$ This distinction is pertinent because men from the Djonler clan gave many of the interviews referenced in this paper. Other key interviews drawn upon are with a Rominag man, a clan whose ancestor was the warrior in the Djonlercaptained boat in these clans' Aru arrival myth, and a Mangar woman whose clan is considered autochthonous to Aru. Each Aru clan has its own story.

Discussions about the Eam Jin song with Batuley elders indicated that the performance of the song contains references of respect and tribute to Lord Urlima, the symbolic meta-person leader of the Urlima moiety. The relationship between Urlima and Eam Jin is sacred knowledge that cannot be detailed here. The key point is that each time the Eam Jin lyric is sung it reinforces ancestral and modern beliefs in how the Urlima-Ursia binary structures relationships in Aru among living humans and meta-persons. This is a teaching. When performing mare songs, Urlima people are even said to have their own way of hitting the hand drums that produces a sound distinct from that of Ursia people.

Batuley people are leading members of the Urlima group. A geographic outlier from the Southern Aru concentration of Urlima people, the midarchipelago Batuley district is bordered by Ursia peoples. These small Batuley

14 For details of the Djonler clan history see Wellfelt and Djonler (2019) 
islands are subject to long periods of drought and onshore winds. The shallow waters make transport difficult, but these coastal seas yield rich harvests of high value resources. For centuries, the annual pearl oyster diving season (four months), supplemented by a biennial/triennial sea cucumber harvest (two-three days), has provided export trade items to allow Batuley people to obtain imported commodities and cash, fueled by international demand for pearl shell, ${ }^{15}$ pearls, ${ }^{16}$ and sea cucumber (trepang) ${ }^{17}$. Discussion of the song Eam Jin with Batuley elders illustrated the novel combination of economic activity and spiritual beliefs that we discuss below.

\section{ECONOMICS AND COSMOLOGY}

In Batuley, as is common in hunter-gatherer societies, the prey (pearl oysters and trepang) exist in a cosmological web of exchange including deities, species masters and ancestors (meta-persons). What is less common among huntergather societies is that in Batuley the prey has long been sold into global markets as a trade good, and rarely consumed directly by the hunters. The interest in capturing the prey (pearl oysters and trepang) derives from export market demand. This is not prey harvested for local consumption in ancient times. The prey is a commodity which has grown cloaks of meaning, just like the growth of a pearl around a grain of sand.

This commodity heritage distinction does not lessen the importance of the prey in Aru backshore people's cosmologies, but in fact it strengthens the social importance as Patricia Spyer $(1997,2000 a)$ demonstrated in an analysis of the relations of debt in Southern Aru between Barakai people (See Map 4), sea-wife deities, merchants, and global markets. Sea-wives are fickle undersea deities who may assist divers in their search for oysters and keep divers safe in this high-risk activity. ${ }^{18}$ The buyers or brokers of the "prey for export" changed over centuries through eras dominated by Arabs, Macassars, Dutch, Japanese, Sino-Indonesian shopkeepers, Bandanese merchants, and Australians. The Celebes Trading Company, the Australian pearling monopoly which enforced

15 The primary commercial demand for the large pearl oyster (Pinctada maxima) that flourishes in the shallow nutrient rich Arafura seas of Aru's east coast is for mother-of-pearl shell exported to be manufactured into buttons and inlays. Pearls are found only on occasion in this type of oyster that grows to $30 \mathrm{~cm}$ in diameter. The shell is the primary commodity. By the seventeenth century European contact and market demand expanded the scale of the existing pre-contact pearl oyster export trade to Asian markets which began a millennium earlier (Andaya 1991: 75).

16 Pearls are uncommon to find in Pinctada maxima but do occur and on occasion are quite large.

17 Certain species of sea cucumber (trepang) are gastronomic delicacies with perceived health properties in Chinese and other Asian markets. One of the most expensive types is sandfish (Holothuria scabra) which flourishes in the inshore waters surrounding Batuley, Barakai and a few other Aru backshore locations. Chinese demand for trepang increased significantly in the mid-seventeenth century stimulating the trade in Southeast Asia (Macknight 2013: 20).

18 In Barakai and Batuley, sea-wives are underseas meta-persons who choose a diver when he finds his first oyster. A sea-wife helps keep the diver safe in this dangerous profession. The sea-wife must be appreciated through gifts from the diver and his land wife and accorded great respect (Spyer 1997, 2000a). 
the service of most backshore pearl divers from the late nineteenth century through the mid-twentieth century was particularly intrusive in Aru (Martinez and Vickers 2015). Today Sino-Indonesians dominate the village level trade in pearl oyster and sea cucumber through family-based networks of village shops and Dobo based consolidators, but this economic disparity is just one aspect of a larger whole.

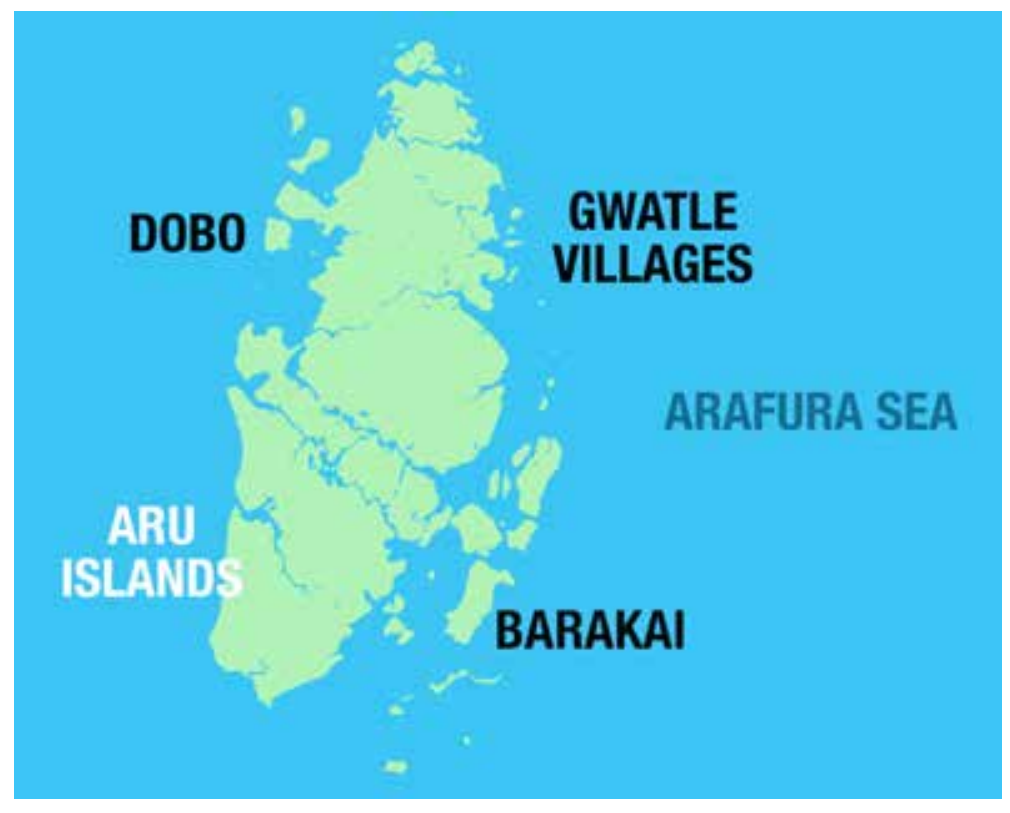

Map 4. The pearl diving communities of Batuley (Gwatle) and Barakai have long standing connections. Their languages share more congruence than with other Aru languages (Hughes 1987).

Ancient Batuley beliefs structuring people's relationships with their prey and associated meta-persons give consistent meaning that resists cultural exploitation. Batuley people's pearl oyster, turtle shell, and sea cucumber harvests have long been in demand, but their resistance to colonial assimilation was not always appreciated, as demonstrated by a Dutch East Indies Company (VOC) employee's description of Aru in 1756.

Those of the eastern side are, on the other hand, the most barbarian people of the world, without any respect or fear, fiercely trusting their impenetrable rocks and mountains, which are inaccessible to Europeans (De Klerk 1894: 29-30).

One of the more subtle ironies raised by this quote is that the resilient Batuley relationships with the meta-persons inhabiting these impenetrable rocks support the Batuley cultural vitality also inaccessible to European comprehension in 1756. A bounded reservoir of this cultural resilience are cryptic song lyrics used in special events such as the Sea Tambaroro practiced into modern times. The lyrics are obtuse to an outsider, but the point of the 
singing, drumming, and dancing is to gain the attention of relevant deities and commune with them. The stories referenced in the songs are shared within Batuley communities, not as an economic activity, but as a means of strengthening culture. What is this intrinsic relationship between economics and culture in Batuley?

\section{THE LIVELIHOOD SEARCH}

Batuley's cultural and linguistic southern cousins on Aru's east coast, the Barakai people, apply the Indonesian term "pencarian" (livelihood) exclusively to sea product collection and trade (Spyer 2000a: L2604). In Batuley, in an interview about the Eam Jin song, a diver told us that "eam kale" (pearl oyster) was the head of the manjari or livelihood search (Gordon and Djonler 2019b: 00:07:05). ${ }^{19}$

"Livelihood search" is a defined aspect of life on the backshore. The movement of the prey as a commodity defines economic relations in Batuley with the outside world. The movement of the prey as a metaphor defines an aspect of the Batuley emotional community. Commodity and metaphor exist in relationship. Commodity may have preceded, but metaphor constructs agency and meaning for Arunese backshore people. Metaphor contains the commodity as a bounded aspect of life on the backshore. This reciprocal interpretation draws upon Spyer's analysis of Arunese backshore communities fetishizing sea wives (Spyer 1997: 516).

Despite being enmeshed and at times abused in complex mercantile exchange networks for their prey, Batuley people attach great importance to their relations with the meta-persons associated with their prey as demonstrated and taught in the song Eam Jin Ben Gwalor Ma. This song is the core song for the Sea Tambaroro festival.

The song shows direct references of respect and tribute to Eam Jin (the mother of all pearl oysters) and Tangolangola jina (the mother of white rumped sea cucumbers) deities we classify as species master meta-persons. Broader meanings for the song arose in our discussions with Batuley elders who described the song as a request or prayer for resources to come from the sea and unspecified overseas places. Similar lyrics for the sea cucumber reinforce the core ideas in the integration of economics and cosmology.

a) The species masters are enriched by beneficence from outside Aru. This flow enriches the channels of Batuley as in the Eam Jin lyric "come from the sea or overseas" and the similar lyric "the mother of ... sea cucumbers comes from the sea, comes from far away".

b) Batuley people are not just sending shells and dried sea cucumbers overseas for the economic receipts. They are sending the abundance generated by the species masters overseas, with hopes of reciprocation

19 The diver used the Batuley term manjari (livelihood), likely a Malay borrowing from the Indonesian mencari (to hunt or look for) (Benjamin Daigle, personal communication). 
of knowledge and power through relationship with others who may turn out to be long lost relatives or meta-persons.

c) Batuley people have responsibilities within this relationship to respect deities of the sea and ancestors local and overseas.

The actual first level buyers of the commodity, be they Dutch, Australians, or Sino-Indonesian merchants, are changeable players in this cycle of meaningful relationships that engage the harvester with unknown end users who may "bring knowledge and power to make Aru bright" ${ }^{20}$. The above three core ideas are teachings available to Batuley people to absorb as cultural meaning referenced in the song lyrics.

The Eam Jin song's meanings evoke metaphorical connections. For these island dwellers, the "sea" and distant overseas places are connected in a reciprocal cycle of knowledge, belief, experience and material goods which connect the local and transnational imaginings in Batuley. This theme of the oysters being taken overseas arises in Spyer's work in Barakai, such as a woman who explains that her ancestors first began wearing clothes that a foreign ship brought back in return for pearl oysters sent across the sea (Spyer 2000a: L2071). The Batuley elder's comment that Eam Jin, the mother of pearl oyster, is nourished from afar to reproduce pearl oysters through the familiar reciprocal movement of wealth adds a metaphorical layer to the pearl of meaning grown around the grain of commodity.

In the Batuley Sea Tambaroro ritual, offerings of betel nuts and leaves, and cigarettes on white plates are placed in the sea in specific places to request Lord Urlima to bring back what he took far away overseas and for Eam Jin to nourish the reciprocal movement of sea resources, knowledge, and imported goods (see Picture 1). ${ }^{21}$ The imported white plates given as offerings gleam like pearl oyster shells and reify the cycle of exchange facilitated by the backshore Arunese with meta-persons of the sea (Spyer 1997, 2000a: 3228). Patricia Spyer's research in the Urlima pearl diving communities in Barakai, demonstrates the reciprocal movement of imported goods purchased from the trade-stores, often on credit, as offerings to sea-wife meta-persons who assist divers with safety and finding shells to repay trade-store debts. Batuley people also make offerings to sea-wives, but the offerings to Urlima imply an international cycle of exchange because Urlima left Aru. Batuley elders discussing the Eam Jin song often mentioned how these offerings pleased Eam Jin as well as Lord Urlima, who's custom is to enjoy chewing betel and smoking tobacco. The meaning of the song Eam Jin is steeped in Aru UrlimaUrsia myths.

20 Interview with H. Djonler (61 years), Dobo, 29-4-2015.

${ }^{21}$ There is a correlation of practice in this ritual with broader South East Maluku beliefs in representative wooden statues that are strategically placed on land to protect a place or crops. These statues are also served betel and cigarettes (Siwa-Lima Museum 2016). 


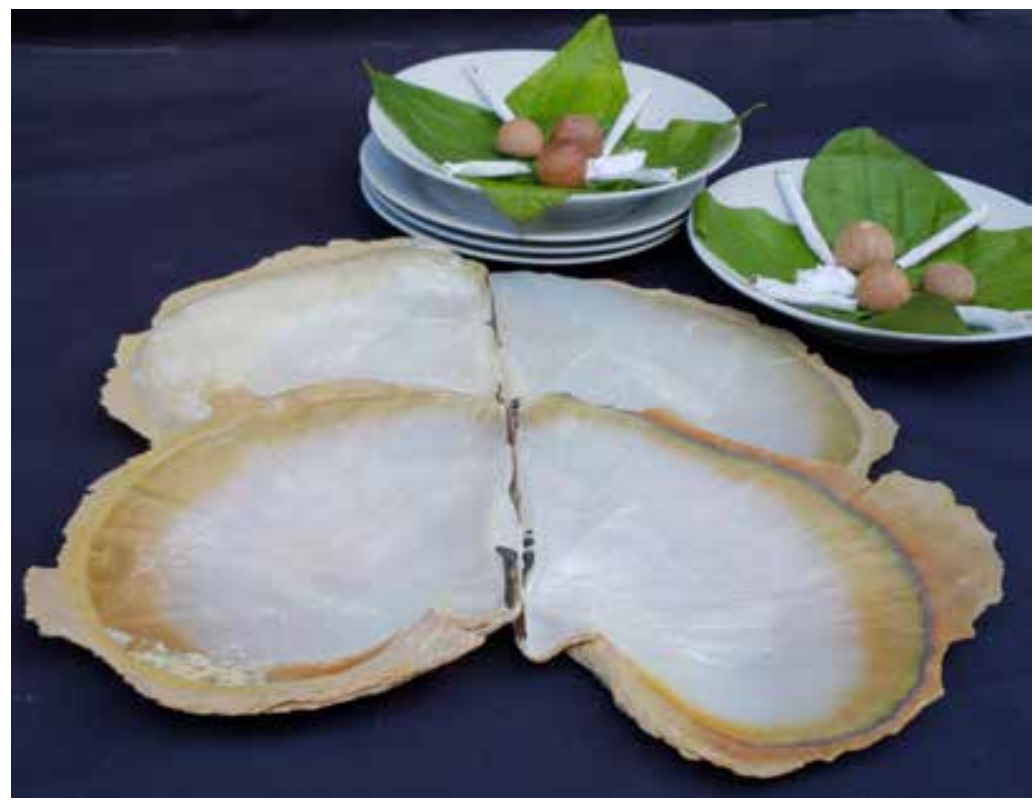

Picture 1. Pearl oyster shells and white plates of offering with betel leaves and nuts, tobacco, and lime (simulation) (Photograph courtesy of Research Results Media 2018).

\section{THE URLIMA-URSIA COMPETITION}

In ancient times Urlima and Ursia were two brothers who competed to achieve the most Aru village allegiances. Urlima took on the skin of a whale and Ursia manifested as a hammerhead shark to travel to each village. Ursia's ability to travel further inland in shallow water led to Ursia acquiring more villages. After the ancient competition between the brothers, Urlima is said to have departed Aru taking his attributes of strength, intelligence, and drive with him, but he made a promise to someday return. Ursia remained in Aru before ascending to the sky to become the morning star (Crawford 1971; Djonler and Gordon 2016: 7). The Urlima-Ursia division of Aru was strengthened in early colonial days when a foreign king arrived in Wokam and appointed a single leader (Rajah) to govern Urlima and five leaders (Patis) for the Ursia people. ${ }^{22}$ Today there are more Ursia villages than Urlima. The disparity remains a sensitive issue. Wars fought between the Urlima and Ursia groups subsided as recently as the mid-twentieth century. This division defines Aru electoral politics to this day. The Urlima-Ursia myth is critical to understand Urlima's role in Batuley reciprocal relationships between near and far, visible and invisible.

22 A trading contract and Act of Conveyance, Submission, and Obedience was made with the Dutch explorer Jan Carstenszoon in 1623, but the record does not mention leadership appointments (Bik 1824). Batuley oral histories suggest the original appointments dividing the governance of Urlima and Ursia people in Aru were made in precolonial times by a visiting king from somewhere in Maluku. The Dutch adopted the existing political structure to govern Aru throughout the colonial era. In any case, the stories suggest that the Urlima-Ursia binary existed prior to imposition of governance by a foreigner. 
In commodity form, Urlima's contribution from afar to a successful harvest of prey yields material wealth. In the metaphorical realm, Urlima's return mends a fractured relationship that symbolizes a healthy emotional community. As a Batuley elder told us:

"so by [giving] this offering then it is impossible that he is not going to come". ${ }^{23}$

The theme of return also arises today in older villagers' perception of an overseas place where all foreigners live coalesced as "Belanda" (Holland). Long lost Arunese relatives gone overseas are thought to reside there, pending their return bearing gifts and knowledge.

Discussions of the Eam Jin song blended the material and metaphorical roles of the "mother of all pearl oysters" and Urlima, two different sorts of meta-persons associated with the sea who energize the flow of commodity and meaning between the local and foreign for Batuley people. Villagers must demonstrate this hoped for energy in lively music and dance in sacred spaces in their village on the cliff above the seashore as described in the lyric sela ngaur (lively cliff).

The Eam Jin song lyric is brief, but it references a complex history and guide to negotiating modern problems for Batuley people to recall each time the lyric is repeated.

"Every teaching is put into a song so that we don't forget it". ${ }^{24}$

History becomes a song; the song becomes a teaching as it is shared with those tasked with leading the community. We provide a further example of this cryptic song lyric practice in a discussion of a mare fat (regular mare song).

\section{Song 2: Dikfer Jar SASen Ru' (They Paddle two layers of Aru)}

The core lyric of this mare fat song is repeated many times by the song leader and participant. The second stanza is inserted intermittently.

Primary lyric

1) Batuley: O dikfer o a, ole dikfer jar sasen ru, ole dikfer $o$.

English literal: O they paddle o a, o they paddle Aru layers two, o they paddle $\mathrm{o}$.

English meaning: O they paddle o a, o they paddle two layers of Aru, o they paddle o.

(Aru layers two is a simplistic translation of jar sasen $r u$, which is examined in detail below).

Secondary intermittent lyrics

2) Batuley: O dikfer tuan fer o $a$.

English literal and meaning: $O$ they paddle, lord of the paddle $o$ a. 
3) Batuley: O dikfer o jar abel o ma dikfer, o dikfer o jar dikfer o lia e. English: $\mathrm{O}$ they paddle, hopefully Arunese are paddling, o they paddle o look Aru paddles.

The mare song Dikfer Jar Sasen $R u$ is sung to a similar rhythm and instrument accompaniment as the song Eam Jin, as described above. Dikfer Jar Sasen Ru is usually sung at a Sea Tambaroro, but the song does not have a prescribed role like Eam Jin song's purpose to launch the festival. In the 2014 Kumul Tambaroro, Dikfer Jar Sasen Ru was sung several times through the night, typically for ten or more minutes of repeating the primary lyric with the secondary lyrics inserted on occasion. The song is also sung at events to celebrate a community member receiving a better position in their workplace or similar advancements in society by individuals. These are positive steps for the person's clan, village, or moiety. When Urlima people sing Dikfer Jar Sasen $R u$ they glorify Lord Urlima. The song is about the ongoing contest in Aru between Urlima and Ursia and their respective followers. The lyric expresses the singers' desire to make Urlima proud of his followers' efforts in the competition. We examine the song Dikfer Jar Sasen $R u$ here because the stories referenced by the song build upon the wisdom and cosmological knowledge discussed for the song Eam Jin.

The phrase, jar sasen ru, has more complex meanings than just two layers of Aru. The most obvious meanings are 1) representation of the competition between Urlima and Ursia and 2) representation of the sky and earth/sea cosmological framework common in Melanesia and East Indonesia, topics discussed below. First, we consider the terms jar and sasen. In Batuley language, jar is a noun meaning the world or universe, but informally jar also means Aru and it is used in the compounds shown in Table 1 along with standalone meanings.

The meanings associated with the word jar given in Table 1 demonstrate the vitality of this word in Aru people's cultural identity, which includes their connections to the world beyond Aru, both physical and meta-physical. In the physical realm, jar abel distinguishes communication of a bounded conception of Aru in contrast with the term jar letan, which conceptualizes Aru's connections with overseas lands and people manifested as the ocean. Batuley people are sea people. Batuley villages are on small islands connected by shallow seas demarcated by channels. People access the sea by foot or dugout canoe to fish, harvest shellfish, tend seaweeds, or travel between villages spending much of their time in or on the littoral seas, which conceptually are similar to land. A medium size channel is a jalen, the common Malay and Indonesian word for street or path. Further offshore Aru's east coast are zones of intermediate depths accessed for pearl diving and fishing (Djonler and Gordon 2016: 92-97). To the west, most trade connections from the Dobo hub mean crossing the deep ocean trench and dangerous seas separating Aru from Kei, Banda, Seram, Mecca, and Europe. Thus, conceptions of the deep seas are of perilous highways of connectedness to ancestors, relatives, 
and meta-persons once left behind on ancestral immigrant journeys to Aru or who have gone abroad and not yet returned. Prominent among these Aru emigrants is Urlima, whose attention the Sea Tambaroro festival music and dance attempts to capture.

\begin{tabular}{|l|l|l|}
\hline $\begin{array}{l}\text { Uses of the word } \\
\text { jar }\end{array}$ & Meaning & $\begin{array}{l}\text { Standalone meaning of } \\
\text { the word compounded } \\
\text { with jar. }\end{array}$ \\
\hline Jar abel & $\begin{array}{l}\text { Aru Archipelago; Aru } \\
\text { Island (Aru alone) }\end{array}$ & Inside; among \\
\hline Jar gwari & $\begin{array}{l}\text { Aru Archipelago; Aru } \\
\text { Island }\end{array}$ & $\begin{array}{l}\text { Island; Gwari village } \\
\text { (Batuley district) }\end{array}$ \\
\hline Jar juer & Arunese person or people & Person; resident \\
\hline Jar keikui & The universe & $\begin{array}{l}\text { Whole; (kekuikui) } \\
\text { complete }\end{array}$ \\
\hline Jar letan & Overseas & Ocean \\
\hline Jar sasen & The layers of Aru & $\begin{array}{l}\text { Something with many } \\
\text { consecutive levels, } \\
\text { such as a history } \\
\text { conceptualized as a tree. }\end{array}$ \\
\hline Jar & $\begin{array}{l}\text { Aru people's self- } \\
\text { characterization of who } \\
\text { and how they are. }\end{array}$ & a \\
\hline Jar & A type of seaweed & n/a \\
\hline Jar & Sick & n/a \\
\hline
\end{tabular}

Table 1. Uses of the word jar in Batuley language from: interviews by the authors, personal communication with Benjamin Daigle, and Daigle (2015).

The meaning of the term jar sasen from Table 1 is critical to understand Arunese conceptions of past, present, and future. A Batuley elder described ancient histories as intertwined visible and invisible tree roots that support the trunk and branches representing multiple layers or levels that comprise the Arunese cultural identity. The jar sasen concept merges Arunese overseas connections into the complexity of the Arunese cultural identity tree. This connectivity of the local and distant is manifested in the Urlima-Ursia dynamic that the song, Dikfer Jar Sasen Ru manifests. In the words of the Batuley Village headman,

"Even overseas there must be only two groups, just Ursia and Urlima, of course there are none else. It is not like religions where there are Islam, Catholic, Protestant et cetera".$^{25}$ 
For Umar Djonler, the outside world and its peoples are an extension of Aru. This is not an uncommon perspective, but the external projection of this unique made in Aru version of the Urlima-Ursia binary is novel.

The term Dikfer translates as "they paddle", but it implies aggressive competition including war, in this case between the meta-person deities, Lords Urlima and Ursia, supported by their respective followers. The followers were described by Batuley elders as " 50 paddlers above [sky] and 50 paddlers below" [earth/sea], the two symbolic layers of Aru. ${ }^{26,27}$ Further contextual background in Eastern Indonesian history and cosmology is required to understand the meanings underlying the cryptic lyrics of the song, Dikfer Jar Sasen $R u$. The history is the teaching.

The cosmological relationship between Sky and Earth, reified as origin story deities, is a common foundational myth in Eastern Indonesia and Melanesian Papua New Guinea. The degree of connection or discord between Sky and Earth determines balance, or lack of balance, in the world. Often these myths involve a conduit of a liana or python connecting Sky and Earth, which may break at times with reconnection encouraged through ritual (Strathern and Stewart 2000: 59-60). The Aru founding myth involves father sky spitting into the ground to make a well from which two boy Rajahs, Urlima and Ursia, emerge to be raised by an old woman on earth. As they grow up, the brothers compete in all things. This sets the scene for the famous competition for village allegiances, marking Arunese people as either Urlima or Ursia supporters. Mythical competitions between brothers generating migrations and origin stories are found the world over (Vansina 1985: 21). What is uncommon in the Aru version is the apparent genesis of the meta-person brothers from relationships structured by competing trade networks.

The greater number of Ursia village allegiances in Aru achieved by Ursia reflects the mythological shark's ability to swim in shallower water to reach inland villages. This inland/coastal settlement demarcation pattern resembles the inland Siwa people versus coastal or trade-focused Lima people moiety relationship recorded in parts of Seram (Valerio 1989: 118-119). The male-sky and female-earth duality is well known in Eastern Indonesian mythology (Strathern and Stewart 2000: 59-77; Valerio 2000: 24). The Aru version of the sky-earth couple bringing forth the two brothers/lords who then define the duality that structures all society is an uncommon elaboration of the sky-earth theme. Although, it is common in the region for non-sky-earth meta-persons to operate independently of the sky-earth deities.

The song Dikfer Jar Sasen Ru emphasizes the history of the discord between the Urlima and Ursia groups, a topic which our interviewees imply is both a cautionary teaching and yet a source of pride in the Urlima group's long resilience. An 1821 Dutch mission to Aru mentions the population division among Orlima (people of five) and Oursia (people of nine) with the latter

26 Interview with H. Djonler (61 years), Dobo, 27-4-2015.

27 Land and sea are not subject to a clear distinction on Aru's east coast where high tide coastal waters become at low tide walkable land or shallows extending offshore for 3-4 kilometres. 
being the larger group. In the fifteenth and sixteenth centuries the scale of the Malukan spice trade grew dramatically alongside the spread of Islam and the Malay language as the lingua franca (Grimes 1991: 87). Aru had longstanding trade relations with Banda by this time (Dijk, Carstenz, and Gonzal 1859: 9; Ellen 2003: 85-86, 102-103; Hanna 1991: 66-67). The original spread of the Urlima-Ursia trade networks into Aru is undated ancient history. In the sixteenth century when Europeans entered the Maluku trade, two trade partnerships, Uli Lima (league of five) and Uli Sewa (league of nine) were long established as a system of village alliances in Maluku (Andaya 1993: 223; Ellen 2003: 84; Grimes 1991: 92).

The Aru division between Urlima and Ursia has roots in this ancient Maluku political dualism (Dolcemascolo 1996: 89; Healey 1995: 56; Valerio 1989: 117). Dutch rule disrupted the pre-colonial export trade system aspect, but the division persisted in Aru daily life and cosmology, and at times sparked violent conflict. In our interviews Batuley people were reticent to speak of details of the historic Urlima-Ursia wars in Aru. As in any civil war, Aru people often have ancestors from both sides of the conflict. The division of allegiance continues in modern political processes. We were told by a Batuley man that the song Dikfer Jar Sasen Ru is sung with pride among Urlima people. In a public setting in another village the topic of conflict in this song was acknowledged by village elders, but the topic was soon changed with elaborate jokes about the absurdity of people paddling the wind in the sky.

The song, Dikfer Jar Sasen Ru, references multi-faceted meanings of past glories, disruptive conflicts, and political allegiances within different layers of cosmological significance formed around the Urlima-Ursia binary in three ways.

First, the song confirms Urlima and Ursia in Arunese mythology as founding deities who travel by water. Different people told us that the deities traveled to the villages by:

a) taking the form of whale and shark;

b) riding the whale and shark; ${ }^{28}$

c) using boats like either a whale or a shark. ${ }^{29}$

Paddle powered water travel has long been the primary means of transport and communication among Batuley villages and is imbued with meaning. In 1623, an early Dutch explorer, Dominé Vertrecht, described Aru military power in 1623 as fleets of canoes that each held 30-40 men (Dijk, Carstenz,

28 In some versions of the story, there were not large boats made yet in this time, so it was necessary to use the whale and shark.

29 A reductive analysis could be that representatives from the Maluku Uli Sewa and Uli Lima trade groups visited Aru and Uli Sewa had boats with less draft than Uli Lima, thus allowing Uli Sewa better access to people living further inland. However, this simplistic analysis of relationship building in Aru is unlikely given the complexity of Aru clans, pela bonds, migrations and known histories, including recent scholarship on the punctuated diffusion of Islam in Aru (Wellfelt and Djonler 2019). 
and Gonzal 1859: 9). In 1646, Vertrecht does not define the size of the crew in the Batuley boats that threaten his ship's safety, but a Batuley boat described as "large" was repelled from coming near Vertrecht's ship, so the Batuley crews must have been a significant force (VOC 1159). Paddling large canoes is simultaneously a metaphor for:

a) cooperation, paddlers must be in synchrony to move a boat effectively;

b) competition, canoe racing has a long history in war and sport in Aru;

c) the energy and drive of Urlima; and hope for Urlima's return, as exemplified in the following song lyric recorded on Aru's west coast: "Hurry up paddle Rajah Urlima, The Rajah will return from afar, paddle" (Crawford 1971: 2).

Second, the 50 paddlers in the sky and the 50 paddlers below reference the broader Sky and Earth framework of Eastern Indonesian and Melanesian ideas of dualistic unity within which the Ursia-Urlima narrative is aligned. The Sky-Earth and Ursia-Urlima binary relationships have different heritages, if the latter relationship arose from commercial trade networks. However, circumstances of significant change may re-energize "remote forms of mythology" (Strathearn and Stewart 2000: 71). The intensification of the Maluku trade in the precolonial era, driven by distant demand and local competition for Aru's resources might energize this blending of commerce, politics, and cosmologies referenced in the song Dikfer Jar Sasen Ru. Such transitions support the concept that dual symbolism and classification are not always bound to morphological dualism (Forth 2000: 10). There is only a rough geographical split in Aru of north/Ursia and south/Urlima, with the addition of Batuley surrounded by Ursia territory on the east coast (Wellfelt and Djonler 2019: 3). In Seram, geographical correlates between the moieties were also inconsistent (Valerio 1989: 118).

Third, the equal number of the 50 paddlers above and 50 paddlers below is a conceptualization representing a model of energetic tension and balance between Sky and Earth that reconcile the Aru Ursia-Urlima frame of tension that is off-balance in numbers of adherents. Aru society has long functioned around this dualistic tension, with cross-clan and inter-village alliances such as pela relationships introducing other balancing factors that cannot be explored here in detail. ${ }^{30}$ For example, the Urlima Batuley people have a longstanding relationship with Ujir, an Ursia Islamic community on an island 20 kilometres north of the Dobo hub. ${ }^{31}$ In recent times Batuley elders have been asked to mediate disputes among Ujir people.

30 See Huwae (1995) for a study of pela relationships in Central Maluku.

31 Vertrecht expresses surprise at the Batuley-Ujir cooperation connection in 1646 (VOC 1159). For histories of the Batuley-Ujir relationship see Gordon, Djonler, and Hägerdal (2019) and Wellfelt and Djonler (2019). 


\section{SUMMARY}

We analysed two important songs from the Batuley 2014 Sea Tambaroro festival. These songs evoked significant discussions with the Batuley elders interviewed in 2015 and 2016. The lyrics of the songs act as referents to deep bodies of knowledge of meta-persons including ancestors, deities, and species masters, such as the mother of all pearl-oysters. The meta-persons are participants in Batuley communities. The knowledge associated with the songs is valued in Batuley. Elders now experiment with sharing their cultural heritage in a book, a film and academic papers, such as this one. This experiment follows the Batuley tradition of keeping cultural heritage relevant with the times but we change the cryptic lyric transmission model. Batuley cosmological beliefs demonstrate remarkable resilience to the forces of modernity, with which Batuley people have dallied for many centuries. We verified factual truth in Batuley oral histories from the eighteenth century elsewhere (Gordon, Djonler, and Hägerdal 2019).

Batuley people retain and transmit a set of teachings based in historical truth that support the self-governance the community's physical location affords. The teachings support the "emotional community" identity giving resilience to a minority language and culture of a community which comprises less than four percent of Aru's population. Batuley cultural history resides in the teachings referenced in cryptic song lyrics. Centuries of historical truths demonstrate Batuley cultural resilience negotiated with forces local and overseas. Relationships with meta-persons give form to the stories that become referents for modern challenges.

Societies subsisting by hunting and fishing are often egalitarian human political structures meshed with cosmologies of "meta-persons, endowed with life-and-death powers over the human population" (Graeber and Sahlins 2017: 24). Such "small scale" societies are often viewed, for good reason, as threatened by commodification and other forces of modernity. Today, many such "societies at risk" exist in geographically remote locations. Subsistence by hunting and artisanal fishing predicates low human population densities that moderate natural resource consumption. Geographic remoteness buttresses perceptions of cultural isolation that define the uniqueness of "endangered" cultures and languages. Batuley is a curious exception to these tropes.

Commodification processes that challenge indigenous cultures are experienced in Batuley with a degree of local agency, despite some historic painful interactions. This agency is partly due to Batuley's geographic location and access to valuable marine resources, but the culture of meaning that envelops the movement of commodities from the sea through Batuley communities and then to export markets is significant. The return flow to Batuley is valued knowledge along with essential and luxury goods, some of which are deposited in the sea to nourish the source. In turn, Eam Jin nourishes the flow. Lord Urlima's journey from village to far off lands with his promise to return signifies the agency of Batuley people in the products they export as commodities. They metaphorically export their central deity, Urlima, overseas 
in a form of reverse colonization. One analytical hypothesis places Eam Jin (earth/sea female) in a foundational but fractured binary relationship with Urlima (sky male) fitting with the Eastern Indonesian archetypes of mother earth and father sky discussed earlier. The mother is close. The father is far away. Following this path, the Batuley ritual encourages reconnection between Sky and Earth to restore cosmological balance.

The unique transformation in Aru of the Siwa-Lima trade rivalry into a primary cosmological brother duo of Ursia and Urlima imbues trade with social meaning and establishes agency. Whether this novel Arunese transformation of "Siwa-Lima trade network" to "Ursia-Urlima deity relationship" has been a positive or negative process is an open question. Despite the centuries of internal strife in Aru between the two moieties, the process has allowed cultural adjustment to the impacts of trade. The search for livelihood is a seasonal affair, but membership in Urlima or Ursia is part of everyday life all year long.

Today institutional religion plays a vibrant role in Batuley life, but many people productively integrate their practices with adat beliefs as discussed elsewhere in relation to the Sea Tambaroro (Gordon and Djonler 2019a). Climate change creates challenges in Batuley. Unpredictable seasonal wind changes and associated drought conditions make village life difficult and in 2014 delayed the start of the sea harvest season and Sea Tambaroro festival by several weeks. Such challenges can erode or reinforce how people value cultural heritage beliefs. At least two southern Batuley villages abandoned the Sea Tambaroro practice because they lost confidence in its potency.

The teachings in Aru's oral traditions are tools that leaders continue to use to negotiate change. As Sonny Djonler learned the historical truths embedded in the cryptic lyrics, he acquired responsibilities for vitalizing Batuley culture. The blending of colonial records with oral history in this article provides context for interactions that become part of the Batuley historic tree. Releasing select content of these teachings to be included in a book, a film, and academic papers is a way for Batuley people to keep their culture relevant to new generations. This is a novel form of sela ngaur (lively cliff) that expands an emotional community.

The stories and interviews discussed here represent insights into teachings and knowledge transmission practices of cryptic song lyrics that give meaning to the commodification of natural resources and economic development. These are uneven processes in Aru, but even blemished pearls of meaning have value. Batuley community leaders share their knowledge to build relationships in Aru and overseas.

The cryptic song lyric as culture transmission method raises questions for future research as to the relationship between modern relevance of cultural knowledge and its enduring continuities. 


\section{REFERENCES}

Andaya, Leonard Y. 1991. "Local trade networks in Maluku in the 16th, 17th, and 18th centuries", Cakalele 2: 71-96.

Andaya, Leonard Y. 1993. The world of Maluku; Eastern Indonesia in the early modern period. Honolulu: University of Hawaii Press.

Badan Pusat Statistik. 2018. "Kabupaten Kepulauan Aru". [Retrieved from: https:/ / keparukab.bps.go.id/publication.html; accessed on 27-4-2019.]

Benda-Beckmann, Franz von and Keebet von Benda-Beckmann. 2011. "Myths and stereotypes about adat law; A reassessment of Van Vollenhoven in the light of current struggles over adat law in Indonesia", Bijdragen tot de Taal-, Land-en Volkenkunde 167 2/3: 167-195.

Bik, Adriaan Johan. 1824 [1928]. Dagverhaal eener reis, gedaan in het jaar 1824 tot nadere verkenning der eilanden Kefing, Goram, Groot- en Klein Kei en de Aroe-eilanden. Leiden: Sijthoff. [Translated into English by Hans Hägerdal.]

Boschmann, Kathryn. 2017. "Speaking of the sacred; Exploring religion, spirituality, and the boundaries of emotional communities through oral history", Oral History Forum d'histoire orale (2017) [Religious individuals and collective identities; Special issue on oral history and religion.]: 1-23. [Retrieved from http:/ / www.oralhistoryforum.ca/index.php/ohf/issue/ view/56/showToc; accessed on 29-4-2019.]

Brown, Ian. 1988. "Spice trade", in: Ainslie T. Embree (ed.), Encyclopedia of Asian History Vol. 3, pp. 514-515. New York, NY: Charles Scribner's Sons.

Crawford, I. M. 1971. "Report on Aru Island mythology". Pontifical Missionary Union. [Unpublished; copy viewed in Rumphius Library, St. Francis Xavier Cathedral, Ambon, Indonesia 5-5-2015.]

Daigle, Benjamin T. 2015. "A grammar sketch of Batuley; An Austronesian language of Aru, Eastern Indonesia". MA thesis, Leiden University. [Retrieved from: https://openaccess.leidenuniv.nl/handle/1887/43444; accessed on 25-4-2018.]

D'Albertis, L.M. 1880. New Guinea; What I did and what I saw. London: Sampson Low, Marston, Searle, \& Rivington.

De Klerk, Reiner. 1894. Belangrijk verslag over den staat Banda en omliggende eilanden aan Zijne Excellentie den Gouverneur-Generaal van Ned.-Indië Jacob Mossel. 's-Gravenhage: n.p.

Dijk, L.C.D, J. Carstenz, and J.E. Gonzal. 1859. Twee togten naar de Golf van Carpentaria: J. Carstensz 1623, J. E. Gonzal 1756: Benevens iets over den togt van G. Pool en Pieter Pietersz. Amsterdam: Scheltema. [Mededeelingen uit het Oost-Indisch Archief no. 1 040676749; Retrieved from: https:/ /www. $\mathrm{kb} . \mathrm{nl} /$ sites/default/ files/docs/carstens-translation.pdf; accessed on 25-42019; The translation of the "Journael van Jan Carstensz. op de ghedaene reyse van Nova Guinea“, in: L.C.D. van Dijk (ed.), Twee togten naar de Golf van Carpentaria was partly taken from J.E. Heeres (1899), The part borne by the Dutch in the discovery of Australia 1606-1765 (Leiden/London); Additional translations by Elise Reynolds and Marianne Roobol.]

Djonler, Sonny A. and A. Ross Gordon. 2016. Marine biology knowledge in Gwatle Kal; An illustrated encyclopaedia. Jakarta: Yayasan Pustaka Obor Indonesia. 
DoBeS "The Language Archive". [Retrieved from: https://tla.mpi.nl/ resource/dobes-archive/; accessed on 25-4-2019.]

Dolcemascolo, Glenn. 1996. "Foreign encounters in an Aruese landscape", Cakalele 7: 79-92.

Ellen, Roy 2003. On the edge of the Banda Zone; Past and present in the social organization of a Mollucan trading network. Honolulu, HI: University of Hawai'i Press.

Forth, Gregory. 2001. Dualism and hierarchy; Processes of binary combination in Keo society. Oxford/New York, NY: Oxford University Press.

Gordon, A. Ross and Sonny A. Djonler. 2019a. "Hope and Energy at the Arafura Sea Shore", Journal of Ritual Studies 33 (02): 1-18.

Gordon, A. Ross and Sonny A. Djonler. 2019b. “Tambaroro” documentary film. [Retrieved from: http:/ / researchresultsmedia.ca/; accessed on 29-4-19.]

Gordon, A. Ross and Sonny A. Djonler. 2019c. "Tambaroro" documentary film trailer. [Retrieved from: http://researchresultsmedia.ca/; accessed on 29-4-19.]

Gordon, A. Ross, Sonny A. Djonler, and Hans Hägerdal. 2019. “The killing of Posthouder Scheerder and Jifar Folfolun (The War of the Breasts); Malukan and Dutch narratives of an incident in the waning days of the VOC", Journal of Southeast Asian Studies 50 (3): 1-22. [DOI:101017/S0022463419000420.]

Graeber, David and Marshall Sahlins. 2017. On Kings. Chicago, IL: Hau.

Grimes, Barbara Dix. 1991. "The development and use of Ambonese Malay", in: Hein Steinhauer (ed.), Papers in Austronesian linguistics No. 1, pp. 83-123. Canberra: Pacific Linguistics Press. [Pacific Linguistics A-81.]

Hanna, Willard A. 1978 [1991 reprint]. Indonesian Banda; Colonialism and its aftermath in the Nutmeg Islands. Banda Neira: Yayasan Warisan dan Budaya Banda Neira.

Healey, Christopher 1995. "Traps and trapping in the Aru Islands", Cakalele 6: 51-65.

Hughes, Jock. 1987. The languages of Kei, Tanimbar, and Aru; A lexicostatic classification. Dallas, TX: SIL Publications. [Retrieved from: http://www. sil.org/resources/publications/entry/37677; accessed on 25-4-2019.]

Huwae, Sylvia 1995. "Divided opinions about Adatpela; A study of pela tamilou-siri-sori-hutumuri", Cakalele 6: 77-92.

Lewis, M. Paul, Gary F. Simons, and Charles D. Fennig (eds). 2015. Ethnologue; Languages of the world. Eighteenth edition. Dallas, TX: SIL International. [Retrieved from: https://www.ethnologue.com/language/bay/22; accessed on 25-4-2019.].

Macknight, Campbell. 2013. "Studying trepangers", in: Marshall Clark and Sally K. May (eds), Macassan history and heritage: Journeys, encounters, and influences, pp. 19-39. Canberra: ANU E Press.

Martinez, Julia and Adrian Vickers. 2015. The pearl frontier; Indonesian labour and indigenous encounters in Australia's northern trading network. Honolulu, HI: University of Hawai'i Press.

Pires, Tomé, 1944. "The suma oriental of Tomé Pires and the book of Francisco Rodrigues. London: Hakluyt Society". [Retreived from: https://archive. 
org/stream/McGillLibrary-136385-182/136385_djvu.txt; accessed on 25-4-2019.]

Portelli, Alessandro. 2017. "Oral history as genre", in: Mary Chamberlain and Paul Thompson (eds), Narrative and genre; Contexts and types of communication, pp. 23-45. London/New York, NY: Routledge.

Rosaldo, Renato. 1980. "Doing oral history", Social Analysis 4: 89-99.

Rosenwein, Barbara H. 2003. "Even the devil (sometimes) has feelings; Emotional communities in the Early Middle Ages", The Haskins Society Journal; Studies in Medieval History 14: 1-14.

Rosenwein, Barbara H. 2006. Emotional communities in the early middle ages. Ithaca, NY: Cornell University Press.

Sahlins, Marshall 2017. "The original political society", in: David Graeber and Marshall Sahlins (eds), On Kings. Chicago, IL: Hau. [Chapter 1.]

Schapper, Antoinette. 2019. "Build the wall!", Indonesia and the Malay World 47: 138, 220-251. [DOI: 10.1080/13639811.2019.1554778.]

Siwa-Lima Museum. 2016. “Display materials”. Ambon City, Indonesia.

Sol, MGR. A.P.C. 2009 [2002]. Sejarah Gereja Katolik di Kepulauan Aru. Jakarta: Frits H. Pangemanan.

Spriggs, Matthew, Sue O'Connor, and Peter Veth (eds). 2006. “The Aru Islands in perspective; A general introduction", The Archaeology of the Aru Islands, Eastern Indonesia, pp. 1-25. Canberra: ANU E Press.

Spyer, Patricia. 1996. "Serial conversion/Conversion to seriality; Religion, state and number in Aru, Eastern Indonesia", in: Peter van der Veer (ed.), Conversion to modernities; The globalization of Christianity, pp. 171-198. London: Routledge.

Spyer, Patricia. 1997. "The eroticism of debt; Pearl divers, traders, and sea wives in the Aru Islands, Eastern Indonesia", American Ethnologist 224 (3): 515-538.

Spyer, Patricia. 2000a. Memories of trade; Modernity's entanglements on an Eastern Indonesian island. Durham, NC: Duke University Press.

Spyer, Patricia 2000b. "'Zaman Belanda'; Song and the shattering of speech in Aru, Eastern Indonesia", Indonesia 70: 53-70.

Stevens, Alan M. and A. Ed. Schmidgall-Tellings. 2010. A comprehensive Indonesian-English dictionary. Second edition. Athens, $\mathrm{OH}$ : Ohio University Press.

Strathern, Andrew and Pamela J. Stewart. 2000. The Python's Back; Pathways of Comparison Between Indonesia and Melanesia. Westport, CT: Bergin and Garvey.

Swan, Caudia. 2015. "Exotica on the move; Birds of paradise in Early Modern Holland, Art History 38(4): 620-635.

Thompson, Paul with Joanna Bornat. 2017. The voice of the past; Oral history. Fourth edition. New York, NY: Oxford University Press.

Tyson, Adam 2011. "Being special, becoming indigenous; Dilemmas of special adat rights in Indonesia", Asian Journal of Social Science 39: 652-673.

Valerio, Valeri 1989. "Reciprocal centers; The Siwa-Lima system in the Central Moluccas", in: David Maybury-Lewis and Uri Almagor (eds), The attraction 
ofopposites; Thought and society in the dualistic mode, pp. 117-142. Ann Arbor, MI: The University of Michigan Press.

Valerio, Valeri. 2000. The forest of taboos. Madison, WI: University of Wisconsin Press.

Vansina, Jan 1985. Oral Tradition as History. Madison, WI: University of Wisconsin Press.

Vivieros de Castro, Eduardo. 1992. From the enemy's point of view; Humanity and divinity in Amazonia. Chicago, IL: University of Chicago Press.

VOC 1159: Relation by Dominé J. Vertrecht about a journey to Tanimbar, Kei and Aru, dated Tanimbar 9 April 1646, f. 175-183. The Hague: Nationaal Archief. [VOC archive, 1.04.02.]

Wallace, Alfred R. 1858. "On the Arru Islands", Proceedings of the Royal Geographical Society of London (2) 3: 163-171.

Wallace, Alfred R. 1869. The Malay Archipelago. Volume II (of II). London: MacMillan and Co.

Wellfelt, Emilie and Sonny A. Djonler. 2019. “Islam in Aru, Indonesia; Oral traditions and Islamisation processes from the early modern period to the present", Indonesia and the Malay World 47(138): 1-24. [DOI: 10.1080/13639811.2019.1582895.]

Wollaston, A.F.R. 1912. Pygmies and Papuans; The stone age today in Dutch New Guinea. New York, NY: Sturgis and Walton Company.

\begin{abstract}
ABOUT THE AUTHORS
A. Ross Gordon is a sessional Lecturer at Kwantlen Polytechnic University, Surrey, and Associate Faculty at St. Stephen's College, Edmonton. Research during a 2015 fellowship at Royal Netherlands Institute of Southeast Asian and Caribbean Studies (KITLV) contributed to this article. His publications include a.o. Nakasaleka: Language, marine ethnobiology, and life on a Fijian Island (PhD thesis of University of Alberta, 2013). Recent publishing co-author credits (with Sonny A. Djonler) include: Marine biology knowledge in Gwatle Kal; An illustrated encyclopaedia (Jakarta: Yayasan Pustaka Obor, 2016) and "Hope and Energy at the Arafura Sea Shore", Journal of Ritual Studies Vol. 33. No. 2 (2019): 1-18. A. Ross Gordon can be contacted at: ross.gordon@kpu.ca.
\end{abstract}

SONNY A. DJONLER holds a bachelors in fisheries from Pattimura University in Ambon. He works as a consultant for the Aru parliament. His interest is in preserving Aru's culture especially Batuley language and culture. Publishing co-author credits include: Marine biology knowledge in Gwatle Kal; An illustrated encyclopaedia (with A. Ross Gordon, 2016), "Islam in Aru, Indonesia" (with Emilie Wellfelt), Indonesia and the Malay World Vol. 47 No. 138 (2019): 160183, and "Hope and Energy at the Arafura Sea Shore" (with A. Ross Gordon), Journal of Ritual Studies Vol. 33. No. 2 (2019): 1-18. Sonny A. Djonler can be contacted at: aduargwari@gmail.com. 